\title{
TECHNICAL AND ECONOMIC ANALYSIS OF USE OF POST-TREATMENT WATER AS A SOURCE OF HEAT FOR HEATING WATER IN BREEDING TANKS
}

Leszek Romański*, Jerzy Bieniek, Przemysław Bukowski, Przemysław Kobel, Tomasz Szuk

Institute of Agricultural Engineering, Wroclaw University of Environmental and Life Sciences

"Corresponding author: e-mail: leszek.romanski@upwr.edu.pl

\begin{tabular}{|c|c|}
\hline ARTICLE INFO & ABSTRACT \\
\hline $\begin{array}{l}\text { Article history: } \\
\text { Received: March } 2017 \\
\text { Received in the revised form: } \\
\text { May } 2017 \\
\text { Accepted: May } 2017\end{array}$ & \multirow{2}{*}{$\begin{array}{l}\text { The paper presents a recommendation on how to use waste heat of } \\
\text { post-treatment water in the balneological institute in Ladek Zdrój } \\
\text { health resort. This heat may be used in stenothermal fish big scale } \\
\text { breeding. The presented innovative solution of a technological breed- } \\
\text { ing line of African sharptooth catfish (Clarias gariepinus) has not } \\
\text { been carried out in practice yet and except for ecological values, it } \\
\text { may soon bring real profits. The presented calculations show that the } \\
\text { analysed technology may bring a real return of the incurred invest- } \\
\text { ment expenditures after approx. } 6.5 \text { years from the moment the pro- } \\
\text { duction was launched. The calculated internal return rate is } 14.25 \% \\
\text { and considerably exceeds the border rate (4\%). As it was shown, there } \\
\text { is an additional possibility of improvement of this profitability } \\
\text { through the use of funding as a part of the Operational Programme } \\
\text { Fisheries and Sea } 2014-2020 \text {. Then, at the funding of investment in } \\
\text { the amount of } 50 \% \text { of qualified costs IRR will increase to } 25.03 \% \text {. } \\
\text { The period of capital return will decrease to approximately } 3.5 \text { years. }\end{array}$} \\
\hline $\begin{array}{l}\text { Key words: } \\
\text { fish breeding, } \\
\text { geothermal water, } \\
\text { heat pump, } \\
\text { production profitability }\end{array}$ & \\
\hline
\end{tabular}

\section{Introduction and objective of the paper}

In the production of fish meat, as in the remaining food production sectors, it is important to produce a valuable product with the lowest costs. African sharptooth catfish (Clarias gariepinus) is one of the freshwater fish species which meets those requirements. Its meat is of the best quality with $20 \%$ content of protein and only $4 \%$ of fat with taste values of panga and, according to some people, of veal (Adamek, 1993). It practically has no fishbones and grows fast. Fish may achieve the mass of 800-1200 g within 6-8 months. However, the best advantage of this species is that from $1 \mathrm{~m}^{3}$ of the tank one can obtain as much as 400-700 kilo of the fish product (Adamek, 2002; David et al., 2009). This great efficiency, in comparison to other fish species, is equivalent to great density of fish in the tank. Realization of such technology is possible since African sharptooth catfish in the moment of oxygen deficiency in water is able to breath additionally with atmospheric oxygen. It is possible because it has a specifically built breathing apparatus (Adamek et al., 2004). 
Necessity of maintaining water temperature at the level of $25-30^{\circ} \mathrm{C}$ is a basic difficulty which influences the production results in our latitude (Adamek, 2008). Thus, water heating at low external temperatures is indispensable. This treatment with the use of conventional heat sources affects the profitability of breeding. The costs of fodder, thus increasing it by water heating costs, may cause that the profitability of investment will be in question. Therefore, finding a cheap heat source is a key problem in this type of objectives. Most often free waste heat from any process may be a good solution. In this paper, authors suggest heat recovery from water used in health resorts for healing baths in balneology. These waters with $36-40^{\circ} \mathrm{C}$ are disposed after use due to hygiene requirements. Such procedure is influenced by the fact that hot water (most often salines of various types) is drawn from geothermal bores and without heating, it has a relevant temperature; sometimes water temperature is adjusted, due to low costs, to the values required in treatments. The issue related to obtaining geothermal water heat (all underground waters above $20^{\circ} \mathrm{C}$ are considered as such) shall be understood from a wider perspective that is very favourable for our country (Górecki, 2006). It is estimated that in the Polish part of north - west and central Europe there are $6225 \mathrm{~km}^{3}$ of geothermal waters. Taking into consideration water temperature, its cooling degree to $25^{\circ} \mathrm{C}$, it was calculated that possible thermal energy resources which can be recovered in the Polish part are 952348800 GJ, which corresponds to 22.7 billion tones of crude oil (Ney, Sokołowski, 1987). In Poland, geothermal water occurs in reservoirs which are located at the depth to $3000 \mathrm{~m}$ and have temperatures which do not exceed $100^{\circ} \mathrm{C}$. It results from the so-called geothermal degree, which in Poland is between 10 to $110 \mathrm{~m}$, on the majority of area it is at the level of $35-70 \mathrm{~m}$. This value means that the temperature increases by $1^{\circ} \mathrm{C}$ with each $35-70 \mathrm{~m}$ of depth (Lewandowski, 2006; www1; $\underline{w w w 5}$ ). Polish geothermal waters are ideal for heating systems. Due to the solutions applied, water leaving the heating system almost always has a temperature high enough to be used additionally for heating other production systems where the temperatures of operation are within $20-40^{\circ} \mathrm{C}$ (Bujakowski, 2007, 2010). Thermal waters used in balneotherapy the most often have high content of mineral salts (Tomaszewska, 2011) and cannot be directly used in fish breeding. On the other hand, with the use of heat pumps, one may use posttreatment water heat and use it for water heating in fish pools. In such a situation, posttreatment water will be treated as a bottom source of a heat pump. Heating water in a pool to the temperature of $25-30^{\circ} \mathrm{C}$ in the top heat source of the pump enables at the same time pump operation at its highest performance (Latała et al., 2011; Rutkowski et al., 2013). For effective breeding at the optimal demand for heat for water heating, African sharptooth catfish breeding may be carried out according to a popular technology in tanks equipped with a water recirculation system (Żelazny, 2007). Due to such technology, heat provided by the heat pump, except for the starting phase of breeding, will be practically used only for supplementation of heat losses.

The objective of the research was technical and economical assessment of the the concept of use of post-treatment thermal water in Lądek Zdrój health resort as heat for heating water in pools with African sharptooth catfish. The assumption of the concept was treating post-treatment water as a bottom heat source of the heat pump. While the top source would heat water flowing to the tanks with fish. 
Technical and economic analysis...

\section{The concept of PC use for heating water in fish breeding tanks}

Healing waters of Lądek Zdrój have a specific composition and cannot be considered as mineral waters. They are described as weakly mineralized, thermal, containing radon, fluoride, sulphide (Ciężkowski, 1980, 2008). Weak mineralization of these waters enables their use in open circulation, which means that after use they may by directly disposed to the surface sewage or municipal sewage system pursuant to the legal water authorization. Such management is possible for waters with considerable resources whose chemical composition is not a threat for natural environment. Table 1 presents the amount of post-treatment sewage from six facilities where water treatments are carried out and which is disposed to the municipal sewage system. These are amounts which can possibly be used for heat recovery. However, the energy potential of Lądek Zdrój waters is considerably higher since expenditure of all sources which outflow automatically may be included in this balance. Kapuściński (1997) states that a long-term efficiency of Lądek Zdrój bed should be stabilized at the level of $q=11 \mathrm{dm}^{3} \cdot \mathrm{s}^{-1}$. Assuming the value of long-term efficiency, the real energy potential may be determined at the level of $346896 \mathrm{~m}^{3} \cdot \mathrm{year}^{-1}$.

Table 1.

Amount of thermal post-treatment water disposed to municipal sewage system

\begin{tabular}{lc}
\hline Year & Amount $\left(\mathrm{m}^{3}\right)$ \\
\hline 2010 & 18193 \\
\hline 2011 & 18202 \\
\hline 2012 & 19363 \\
\hline 2013 & 19121 \\
\hline 2014 & 19647 \\
\hline & Source: Author's own study based on the archive of Ladek Zdrój health resort, www2
\end{tabular}

In practice, in Poland electric and gas energy has been used in a newly created stenothermal fish breeding in Poland. This heating system can be easily automatized, which considerably ensures correctness of production. In the suggested solution, replacement of these conventional heating methods with a heat pump is taken into consideration. Posttreatment water (post-treatment sewage) from health resort facilities and thermal water from "Zdzisław" source will be used for its functioning as a bottom heat source. The suggested system of hot water preparation will be monovalent, which means that the heat pump will be the only one and sufficient source (Brodowicz, Daykowski, 1990; Rubik, 2011). Water heating in the discussed facility will take place according to the scheme presented in figure 1.

\section{Characteristics of the heating water system in fish breeding tanks}

African sharptooth catfish is a stenothermal fish and thus it must be heated in cycles to the required temperature, in particular in periods with low temperatures. Thus, fish breeding should be carried out in tanks with water circulation due to profitability of production (Helfrich, Libey, 1991; Akinwole, Faturoti, 2007; Endut et al., 2010). This technology 
enables purification, treatment and heating of water in tanks to the value resulting from the temperature losses instead of its replacement.

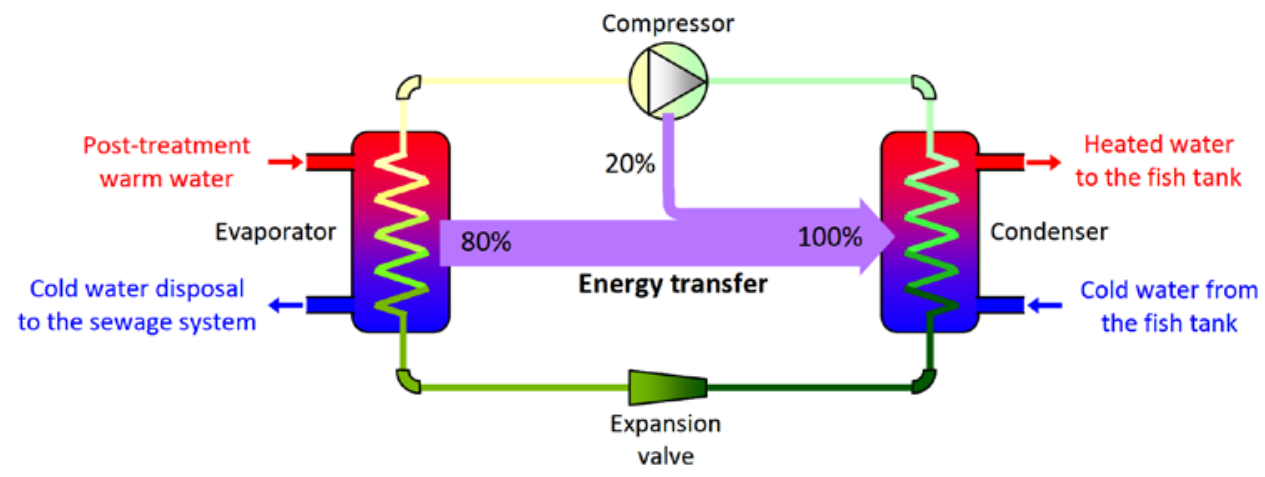

Figure 1. Concept of heat pump use for heating water in fish breeding tanks

Source: Author's own study based on [10]

Figure 2 presents a technological scheme of the installation that enables economic and intensive breeding of stenothermal fish. Functioning of the technological circulation is as follows: treated and heated water from the control station of its quality 13 (temperature, $\mathrm{pH}$ reaction, oxygen and nitrogen content are checked is provided to production tanks with 1 inlet pipe of treated water 14).

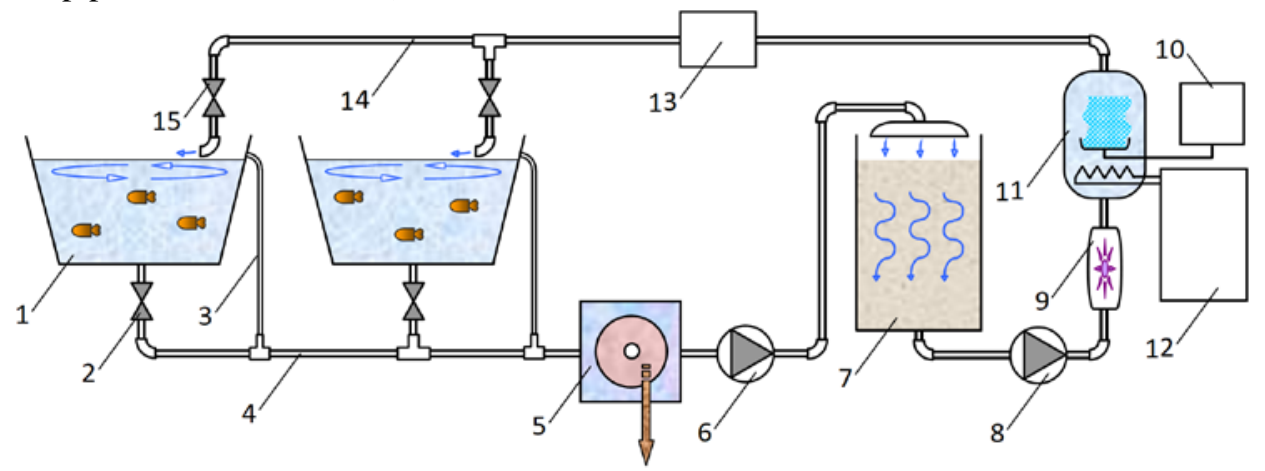

1 - production tank, 2 - valve, 3 - flow pipe, 4 - cumulative pipe, 5 - microscreen, 6 - pump, 7 - sand filter, 8 - pump, 9 - sterilizer, $10-\mathrm{O}_{2}$ generator, 11 - oxidiser, 12 - heat pump, 13 - control and measurement station, 14 -treated water pipe, 15 - valve

Figure 2. Technological scheme of stenothermal fish breeding installation

Valves 15 control the amount of flowing water. In order to put water in tanks in motion, its flow takes place with a pipe placed in contact with the tank edge. Valve 2 ensures balance in water inflow and outflow. Tank outlfow is always located in a way that enables free removal of fish fecas, which gather at the bottom of the tank, by flowing into the cumula- 
Technical and economic analysis...

tive pipe 4. Flow pipe 3 is an additional safeguard for maintaining the required level in a tank and securing the pour-out of water. Water after leaving tanks flows into microscreen 5 , where thicker contamination is separated. After initial water cleaning, pump 6 pumps it to the sand filter 7. Here, on a biological bed, organic substances are decomposed to $\mathrm{CO}_{2}$, $\mathrm{H}_{2} \mathrm{O}$ and $\mathrm{NH}_{3}$ and nitrification as well as denitrifcation to the gas nitrogen $\mathrm{N}_{2}$ takes place. From this place, water tank 8 presses it to sterilizer 9 where UV lamp, which disinfects water by killing bacteria, viruses, fungi, algae, cysts, is the main element. Clean water is provided to oxidizer 11 to which oxygen is provided from $0_{2}$ generator 10 . Water is heated to the required temperature in the oxidiser because a heat exchanger, which is the upper heat source of heat pump 12, is located therein. Treated water parameters are verified during its flow to tank 1 by the control and measurement station 13 .

\section{Economic analysis of the suggested investment}

Organizational and technical assumptions

1. A breeding period from fry to a fish for sale is 8 months from April to November of each year,

2. Breeding is carried out in the open cycle with an annual purchase of fry of 5 kilo,

3. The final weight of the fish for sale is 1.2 kilo,

4. Nutrient value is at the level of 1

5. Final production of fish is 30 tonnes,

6. For the first 4 months fry and then fish between 1 and 2 year of age will be placed in the half of breeding tanks,

7. In the following 4 months, adult fish will stay in all 10 tanks,

8. Daily post-treatment water resources with the temperature of $30^{\circ} \mathrm{C}$ are $53 \mathrm{~m}^{3}$, from which $1230 \mathrm{kWh}$ of heat daily will be recovered after heat loss and temperature decrease to $10^{\circ} \mathrm{C}$,

9. Taking into consideration the assumed production scale and water demand for 1 piece, and that temperature reduction in tanks will not exceed $5^{\circ} \mathrm{C}$ ( 1.5 kilo of water), it seems that daily heat inflow in the amount of $262 \mathrm{kWh}$ in one production cycle $1230 \mathrm{kWh}$ should be ensured,

10. For recovery of this heat an exemplary heat pump Vitocal 300 G, BWS 301. A21 type with the following parameters (www4) was used:

- rated thermal power: $30.19 \mathrm{~kW}$,

- cooling performance: $25.03 \mathrm{~kW}$,

- electric power consumption: $5.5 \mathrm{~kW}$,

- COP effectiveness degree 5.5

11. Energy consumption by the heat pump which heats tank water was determined by assumption that it will work $8.6 \mathrm{~h}$ a day,

- for the first 4 months, electric energy demand will be $2885 \mathrm{kWh}$,

- in the second stage of production of 4 months, the electric energy consumption will be 5 $770 \mathrm{kWh}$,

12. Energy consumption to the drive of particular elements of installation and lighting will be $2440 \mathrm{kWh}$. 
Assumptions to the financial analysis

1. A 10-year financial projection period i.e. 2017-2026 was taken into consideration.

2. The starting point for financial projections was 2017 - treated as a base year.

3. Financial forecasts were made in annual periods.

4. All value data were expressed in PLN.

5. Cash flows were made in net values - treating VAT as a money transfer.

6. Income tax rate is $19 \%$.

7. Changes in the working capital net.

8. Financial analysis uses real discount rate.

9. Fixed prices were used.

10. Demand in the entire period was planned at the permanent level.

11. The entire production in a given year will be sold in the same year.

12. Investment undertaking is financed from own funds.

13. Funding from the Operational Programme Fisheries and the Sea 2014-2020.

Investment inputs

In order to initiate commodity production of African sharptooth catfish, the following investment inputs will be indispensable:

1. Building of the area of $154 \mathrm{~m}^{2}$ and height of $4 \mathrm{~m}$ made in light technology, from preisolated board with roof windows and LED lighting, where fish breeding will be carried out,

2. 10 tanks made of plastic located in two rows in the longitudinal production room with the active cubature $7.2 \mathrm{~m}^{3}$ each (dimensions of the tank $3 \times 2 \times 1.5 \mathrm{~m}$ ),

3. Remaining indispensable installations according to the schematic representation in figure 2 .

4. Heat pump Vitocal 300 G, type BWS 301.A21, storage reservoir.

Table 2 presents a detailed specification of investment expenditures with their costs.

Table 2.

Investment plan for setting up production, Source: author's own study

\begin{tabular}{lcccccc}
\hline Specification & Amount & $\begin{array}{c}\text { Net } \\
\text { price } \\
\text { (PLN) }\end{array}$ & $\begin{array}{c}\text { Net } \\
\text { value } \\
\text { (PLN) }\end{array}$ & $\begin{array}{c}\text { VAT } \\
\text { rate } \\
(\%)\end{array}$ & $\begin{array}{c}\text { VAT } \\
\text { amount } \\
\text { (PLN) }\end{array}$ & $\begin{array}{c}\text { Gross } \\
\text { value } \\
\text { (PLN) }\end{array}$ \\
\hline $\begin{array}{l}\text { Heat pump with } \\
\text { installation (PLN) }\end{array}$ & 1 & 82000.00 & 82000.00 & $23 \%$ & 18860.00 & 100860.00 \\
\hline Storage reservoir (pcs) & 1 & 40000.00 & 40000.00 & $23 \%$ & 9200.00 & 49200.00 \\
\hline Breeding tanks & 10 & 8000.00 & 80000.00 & $23 \%$ & 18400.00 & 98400.00 \\
\hline Building (m ${ }^{2}$ ) & 154 & 3200.00 & 492800.00 & $23 \%$ & 113344.00 & 606144.00 \\
\hline $\begin{array}{l}\text { Installations } \\
\text { in the building }\end{array}$ & 1 & 100000.00 & 100000.00 & $23 \%$ & 23000.00 & 123000.00 \\
\hline Total & & & 794800.00 & & 182804.00 & 977604.00 \\
\hline
\end{tabular}


Technical and economic analysis...

Operational costs

Operational costs related to production of African sharptooth catfish were estimated based on the assumed production scale. Fodder costs were calculated based on dietary recommendations, nutritive rate and market price. The fry purchase cost was determined based on the demand resulting from the planned production scale (with 20\% reserve) and market price.

The electric energy cost was evaluated based on the power installed in devices and time of their operation resulting from the specificity and determined production size. Energy price was assumed according to the market rates offered by energy suppliers for enterprises. Costs of service resulting from employing 1 person under civil law contract for 8 months were also determined.

The amortization charges were defined based on the amortization rates compliant to the Fixed Measures Classification. All fixed measures were amortized with the linear method. It was provided that the building would last 40 years and the remaining devices -10 years. Moreover, current costs related to maintaining infrastructure at the level of $10 \%$ of the annual amortization charges were planned. The operational costs were set in the system of fixed and variable costs (table 3 and 4).

Table 3.

List of fixed costs, Source: author's own study

\begin{tabular}{lcccccr}
\hline Specification & Amount & $\begin{array}{c}\text { Net price } \\
(\mathrm{PLN})\end{array}$ & $\begin{array}{c}\text { Net value } \\
\text { (PLN) }\end{array}$ & $\begin{array}{c}\text { VAT amo- } \\
\text { unt (\%) }\end{array}$ & $\begin{array}{c}\text { VAT } \\
\text { amount } \\
(\mathrm{PLN})\end{array}$ & $\begin{array}{c}\text { Gross value } \\
\text { (PLN) }\end{array}$ \\
\hline Amortization & - & - & 42520.00 & $23 \%$ & 9779.60 & 52299.60 \\
\hline $\begin{array}{l}\text { Electric energy } \\
(6.56 \%)\end{array}$ & 11095.00 & 0.50 & 5547.50 & $23 \%$ & 1275.93 & 6823.43 \\
\hline Employment & 8.00 & 2500.00 & 20000.00 & $23 \%$ & 4600.00 & 24600.00 \\
\hline $\begin{array}{l}\text { Maintaining } \\
\text { infrastructure }\end{array}$ & - & - & 4252.00 & $23 \%$ & 977.96 & 5229.96 \\
\hline Total & & & 72319.50 & & 16633.49 & 88952.99 \\
\hline
\end{tabular}

Table 4.

List of fixed costs, Source: author's own study

\begin{tabular}{lcccccr}
\hline Specification & Amount & $\begin{array}{c}\text { Net price } \\
\text { (PLN) }\end{array}$ & $\begin{array}{c}\text { Net value } \\
\text { (PLN) }\end{array}$ & $\begin{array}{c}\text { VAT } \\
\text { amount } \\
(\%)\end{array}$ & $\begin{array}{c}\text { VAT } \\
\text { amount } \\
\text { (PLN) }\end{array}$ & $\begin{array}{c}\text { Gross } \\
\text { value } \\
\text { (PLN) }\end{array}$ \\
\hline Fry & 25500.00 & 0.50 & 12750.00 & $23 \%$ & 2932.50 & 15682.50 \\
\hline Fodder & 30000.00 & 4.00 & 120000.00 & $23 \%$ & 27600.00 & 147600.00 \\
\hline Total & & & 132750.00 & & 30532.50 & 163282.50 \\
\hline
\end{tabular}




\section{Income}

The main income will come from sale of adult fish whose weight is 1.2 kilo for PLN 11 net for 1 kilo. The first income is planned to be obtained in the second year of investment, i.e. 2018, it will amount to PLN 330000 net and according to the assumptions, it will be at the identical level for the next 8 years.

Moreover, according to the methodology of assessment of investment effectiveness, in the last year of financial projection a book residual value of investment was included at the income side. This value results only from the current value of the building which in the 10th year of investment is at the level of PLN 369000 (after taxation it is PLN 299376 ). The remaining fixed costs were totally amortized at this time.

\section{Assessment of investment effectiveness}

In order to assess effectiveness of investment, the dynamic method was used, i.e. discount payback period, net present value and internal return rate. The assessment was carried out with the use of net advantage in the form of free cash flow to firm. In this formula, operative profit earnings before deducting interest and taxes which were subjected to taxation (NOPAT) were assessed.

$$
\mathrm{EBIT}=\mathrm{P}-\mathrm{VC}-\mathrm{FC}-\mathrm{A}
$$

$\mathrm{P} \quad$ - income

VC - variable costs

FC - fixed costs

A - amortization

$$
\text { NOPAT }=\mathrm{EBIT} \cdot(1-\mathrm{T})
$$

EBIT - operative profit

$\mathrm{T}-$ taxation

$$
\text { FCFF } t=\mathrm{NOPAT}_{\mathrm{t}}+\mathrm{A}_{\mathrm{t}}-\Delta \mathrm{KON}_{\mathrm{t}}-\mathrm{CAPEX}_{\mathrm{t}}+\mathrm{RV}
$$

NOPAT - net operating profit after tax

RV - residual value

CAPEX - investment expenditures

KON - net rotational capital

Free cash flows in the years of financial projections were discounted with the use of the discount rate use at the level of $4 \%$ which is recommended in financial projects from the EU funds.

The presented investment according to calculations presented in table 5 may bring a real return of incurred investment inputs after approx. 6.5 years from launching the production. Profitability of investment measured with NPV (sum of discounted flows in the period of financial projections) amounts to PLN 484096.66 which means recovery of the invested amount, obtaining the return rate from the investigated capital at the level of $4 \%$ and obtaining current surplus over excepted return rate in the amount PLN 484096.66 (Mielcarz and Paszczyk, 2013). 


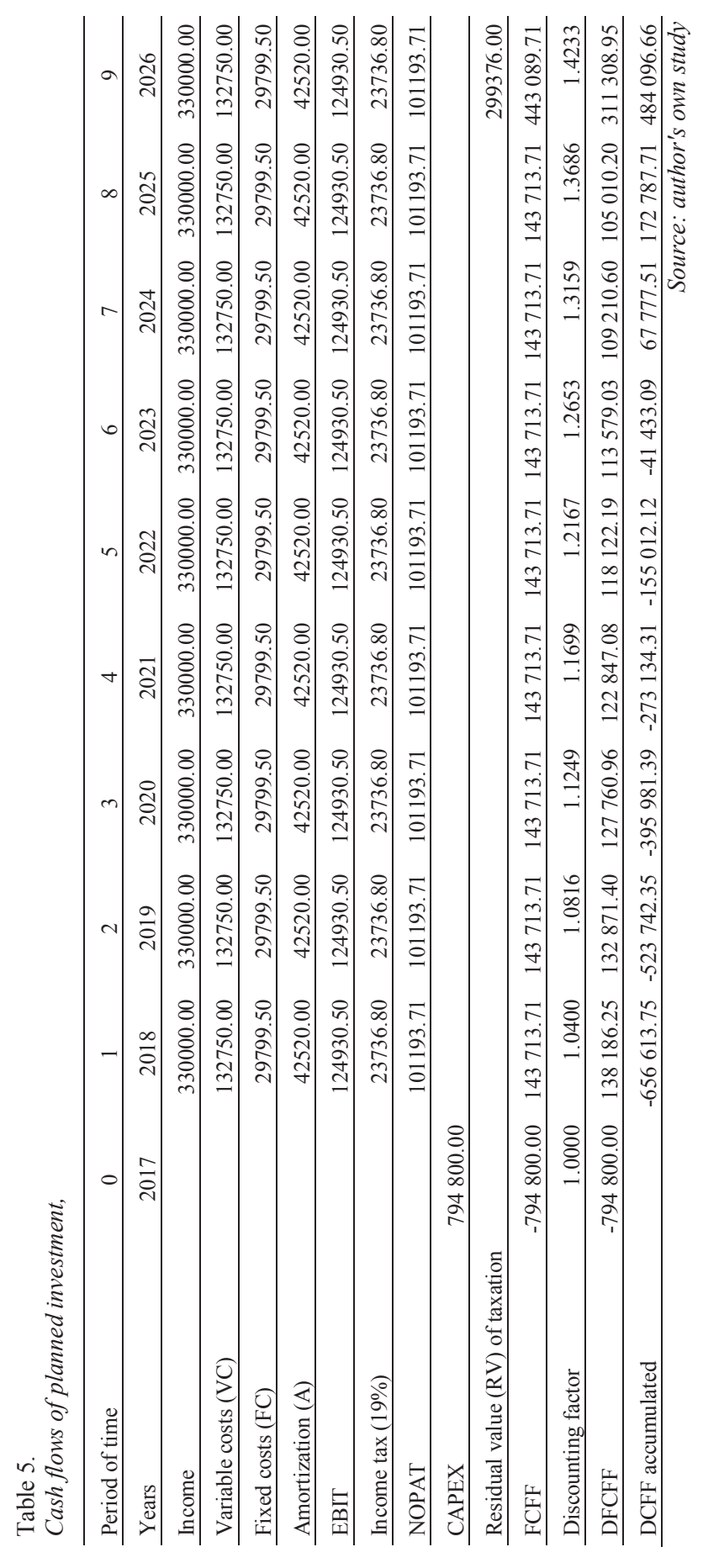


The calculated internal return rate is $14.25 \%$ and considerably exceeds the border rate (4\%). The level of calculated rates indicated a considerably high level of profitability of African sharptooth catfish breeding with the use of post-treatment water in conditions of Lądek Zdrój health resort. One should pay attention to the possibility of further improvement of this profitability through the opportunity to use funding as a part of the Operational Programme Fishery and the Sea 2014-2020, priority 2 "Fostering environmentally sustainable, resource-efficient, innovative, competitive and knowledge-based aquaculture". One may obtain funding for realization of the subject investment in the amount of $50 \%$ of the qualified costs to the amount which exceeds PLN 500 thousand. The simulation of covering of the half of investment costs with the aid from this programme affected the improvement of the investment effectiveness which was translated into the planned minimization of the discounted return period to more than 3.5 years and the NPV value increase to PLN 793 610.12 and IRR to $25.03 \%$.

\section{Conclusion}

African sharptooth catfish is not often bred in Poland since it requires maintaining water temperature at the level of $25-30^{\circ} \mathrm{C}$. It is the only disadvantage since other rates, like mass increase, meat quality or production efficiency are high in comparison to other fish species. Water heating with traditional fuel (hydrocarbon) results in high costs, which eliminates the above - indicated advantages. Thus, the object of the research was to suggest an installation which would enable waste heat use and reduction of these costs.

The economic analysis which was carried out indicated profitability of African sharptooth catfish breeding with the use of geothermal post-treatment water in Lądek Zdrój health resort as a heat for water heating in production tanks. The obtained final results of the applied methods of investment effectiveness evaluation prove a considerably high value of profitability of the planned undertaking, where the return of incurred investment expenditures will take place after 6.5 year from the moment of starting the production.

The use of waste heat of geothermal water in order to increase the energy effectiveness of aquaculture constitutes one of the detailed aims of priority no. 2 of the Operational Programme Fisheries and the Sea 2014-2020. Simulation of the use of aid funds from this programme raised the attractiveness of the discussed undertaking through a considerable improvement of its economic effectiveness since the internal return rate is at the level from $14.25 \%$ and may raise to $25.03 \%$, and the capital return period will drop to approximately 3.5 year. Also the fact that the use of waste heat for raw food material production purposes will result in reduction of fossil fuels consumption and thus to reduction of natural environment pollution, cannot be undermined.

Various concepts of an installation were analysed for the purposes of this material. The most advantageous from the economic point of view were tanks with recirculation where water is not replaced with new one, but purified and treated as well as heated to the the heat value resulting from temperature losses. A technological scheme of the installation was showed, its cost was determined and costs related to its exploitation were calculated.

The example described in the article illustrates how the use of waste heat and heat pumps may extend possibilities of fish meat breeders by introduction to the national production fish species which have been available in Poland only as an imported good so far. 
Technical and economic analysis...

\section{References}

Adamek, J. (1993). Rozród i podchów wylęgu suma afrykańskiego (Clarias gariepinus), Komunikaty rybackie, 6, 3-5.

Adamek, J.(2002). Wyniki chowu narybku suma afrykańskiego Clarias gariepinus (Burchell 1822) w różnych zagęszczeniach, Komunikaty rybackie, 6, 5-7.

Adamek, J. (2008). Sum afrykański. Technologia chowu. Wyd. IRS. ISBN: 978-83-60111-35-2

Adamek, J., Irnazarow, I., Pilarczyk, A., Żelazny, H. (2004). Transportation efekt on african catfish stock material. Zeszyty Naukowe AR Wrocław Zootechnika. 505, 24-31.

Akinwole, A., Faturoti, E. (2007). Biological performance of African Catfish (Clarias gariepinus) cultured in recirculating system in Ibadan. Aquacultureal Engineering, vol. 36(1), 18-23.

Brodowicz, K., Dyakowski T. (1990). Pompy ciepła. PWN, Warszawa. ISBN: 83-01-0981-7.

Bujakowski, W. (2007). Wykorzystanie wód geotermalnych $w$ kontekście: klimatycznym, rekreacyjnym, balneologicznym i ciepłowniczym. Studia, Rozprawy, Monografie 76, 7-24. PAN Instytut Gospodarki Surowcami Mineralnymi i Energią, Kraków.

Bujakowski, W. (2010). Wykorzystanie wód geotermalnych w Polsce. Przegląd Geologiczny. Vol.58, 7, 580-588.

Ciężkowski, W. (1980). Hydrologia i hydrochemia wód termalnych Lądka Zdroju. Problemy Uzdrowiskowe z. 4(150), 28-32.

Ciężkowski, W. (2008). Lądek Zdrój. DWE, Wrocław. ISBN: 978-83-7125-165-8.

David, P., Pop, A., Popovici, V. (2009). Considerations upon energetic efficiency of a reculating aquatic system for super intensive fish culture. AACL Bioflux, 2(2), 155-159.

Endut, A., Jusoh, A., Ali, J., Hassan, A. (2010). A study on the optimal hydraulic loading rate and plant ratios in recirculation aquaponic system. Bioresource Technology, Vol. 101, 5, 1511-1517.

Helfrich, L., Libey, G. (1991). Fish farming in recirculating aquaculture systems (RAS). Virginia State Cooperative Service,

Górecki, W. (2006). Atlas zasobów geotermalnych formacji mezozoicznej na Niżu Polskim. AGH. Kraków. ISBN: 978-83-88927-14-0

Kapuściński, J., Red. (1997). Zasady i metodyka dokumentowania zasobów termalnych i energii geotermalnej oraz sposobów odprowadzania wód zużytych. Poradnik metodyczny. MOŚZNiL, Warszawa. ISBN: 83-85284-27-3

Latała, H., Kurpaska, S., Sporysz, M. (2011). Wybrane aspekty współpracy pompy ciepła z gruntowymi wymiennikami ciepła. Inżynieria Rolnicza, 6(131), 117-124.

Lewandowski, W. (2006). Proekologiczne źródła energii odnawialnej. WNT, Warszawa . ISBN: 83204-3112-3.

Ney, R., Sokołowski, J. (1987). Wody geotermalne Polski i możliwość ich wykorzystania. Nauka Polska 6. 67-92.

Mielcarz, P., Paszczyk, P. (2013). Analiza projektów inwestycyjnych w procesie tworzenia wartości przedsiebiorstwa. PWN, Warszawa. ISBN: 978-83-01-16059-3.

Rubik, M. (2011). Pompy ciepła w systemach geotermii niskotemperaturowej. MULTICO Oficyna Wydawnicza, Warszawa. ISBN: 978-83-7763-052-5.

Rutkowski, K.,Vogelgesang, J., Latała, H., Kempkiewicz, K. (2013). Efektywność pomp ciepła współpracującej ze zbiornikiem buforowym o zmiennej pojemności. Inżynieria Rolnicza, 3(146), 309-320.

Tomaszewska, B. (2011). The use of ultrafiltration on reverse osmosis in the desalination of low mineralized geotermal waters. Archoves of Environmental Protection, (37)3, 63-77.

Żelazny, H. (2007). Wymiana ciepła między wodą w basenach do kontrolowanego chowu ryb ciepłolubnych a otoczeniem. Inżynieria Rolnicza 9, 289- 295.

www.googlemaps.com.pl

www.uzdrowisko-ladek.pl

www.nowoscibudowlane.pl

www.vissmann.pl. Wytyczne projektowe. Pompy ciepła Vitocal

www.stat.gov.pl 


\title{
TECHNICZNO-EKONOMICZNA ANALIZA WYKORZYSTANIA WÓD POZABIEGOWYCH JAKO ŹRÓDŁA CIEPLA DO PODGRZEWANIA WODY W BASENACH HODOWLANYCH
}

\begin{abstract}
Streszczenie. W pracy przedstawiono propozycję wykorzystania ciepła odpadowego wody pozabiegowej w zakładach balneologicznych w Uzdrowisku Lądek Zdrój. Ciepło to może być wykorzystane $\mathrm{w}$ chowie ryb ciepłolubnych na dużą skalę. Zaprezentowane rozwiązanie innowacyjnej linii technologicznej chowu suma afrykańskiego (Clarias gariepinus) nie jest jeszcze realizowane w praktyce, i oprócz walorów ekologicznych także w szybkim czasie może przynieść realne zyski. Z przedstawionych obliczeń wynika, że analizowana technologia może przynieść realny zwrot poniesionych nakładów inwestycyjnych po około 6,5 roku od uruchomienia produkcji. Obliczona wewnętrzna stopa zwrotu (IRR) kształtuje się na poziomie 14,25\% i znacznie przekracza stopę graniczną (4\%). Jak wykazano, istnieje dodatkowa możliwość poprawy tej rentowności poprzez wykorzystanie dofinansowania w ramach Programu Operacyjnego Rybactwo i Morze 2014-2020. Wtedy, przy dofinansowaniu inwestycji w wysokości 50\% kosztów kwalifikowanych IRR wzrośnie do 25,03\%. A okres zwrotu kapitału spadnie do ok. 3,5 roku.
\end{abstract}

Słowa kluczowe: chów ryb, wody geotermalne, pompa ciepła, opłacalność produkcji 